\title{
Investigating the Relationship between Volitional Strategies and Academic Achievement in a Flipped Learning Environment
}

Bengi Birgili', Fatma Nevra Seggie ${ }^{2}$ and Zeynep Kızıltepe ${ }^{2}$ ${ }^{1}$ MEF University, Faculty of Education, Department of Mathematics and Science Education

${ }^{2}$ Boğaziçi University, Faculty of Education, Department of Educational Sciences

\section{Abstract}

This study was conducted to determine whether there is a relationship between academic volitional strategies and academic achievement in a flipped learning environment. Academic achievement entails an environment where students exert self-discipline on classroom tasks. By using volitional strategies, learners can enhance engagement on academic tasks and complete assignments more efficiently. Undergraduate students enrolled in a teacher education programme at a higher education institution in Turkey participated in the research. Academic Volitional Strategies Inventory (AVSI), with $\alpha=.87$ internal consistency, was applied to a group of students. The obtained data were explored through Pearson correlation. The results showed a statistically significant positive relationship between AVSI scores and academic achievements $(r=.39, p=<.05)$. Hence, volitional skills and academic achievements act in concert in a teacher education programme.

Key words: correlational study; flipped learning; higher education; self-regulated learning; teacher education.

\section{Introduction}

Several aspects in relation to subject domain define achievement. Generally, it is reaching an intended stage successfully, with effort, skill and courage. Achieving school success demands an environment where students need self-discipline to complete school responsibilities. In other words, self-discipline is a pre-requisite for students in order to engage in school related tasks and develop work habits. This leads to 
successful accomplishment of their school challenges. Hence, these positive habits can be associated with students' self-regulatory behaviour (Bandura, 1986; Bembenutty, 2009; Pekrun et al., 2004). The greater the management of the learning environment, the better students can concentrate on academic tasks (Burić \& Sorić, 2012; McCann $\&$ Turner, 2004). In addition, maintaining motivation and regulating emotions are important aspects of students' academic performance. Positive educational outcomes stem from the amount of students' engagement with self-regulatory activities. These self-regulatory skills are also activated when individuals take responsibility, and are open to learning as well as being motivated actively and metacognitively (Cooper \& Corpus, 2009; Fredricks, Filsecker, \& Lawson, 2016; Zimmerman, 1990). Pekrun (2000) asserts that activation of positive feelings as "belief to be successful" or "enjoyment of learning" contribute to eagerness to learn and task-focused interest. This motivation leads to the use of several learning strategies that result in achievement in the learning process (Ketonen, Dietrich, Moeller, Salmela-Aro, \& Lonka, 2017; Ouellet, 2017; Pekrun \& Stephens, 2012).

In recent studies, self-regulatory activities have been related to information processing theory indicating elaboration, organization, and rehearsal, in which the use of metacognitive and cognitive skills is the primary focus. However, recent studies identified an inclination to the idea that constant effort and perseverance of students with the task obligations were enhanced by self-regulation (Langer, Frie, \& BohnGettler, 2017; Madden, Lynch, \& Doe, 2015; McMahon \& Luca, 2001; Shepherd, 2006). Namely, self-directedness, effort, and perseverance or persistence toward goal attainment are considered important constructs to self-regulatory control (McCann \& Garcia, 1999). One's attention and persistence toward task requirements are seen as prerequisites to positive learning outcomes, success, and achievement.

Turkey is confronted with the struggle against inequality of educational opportunity (Ferreira \& Gignoux, 2010). There are many achievement gaps in the results of international high-stake examinations. Studies show that students do not have sufficient knowledge, skill, or dispositions compatible with $21^{\text {st }}$ century skills. However, they are the citizens of their society who are responsible for shaping the future. Hence, as practitioners, we should know more about how we can advance tools and methods in the education system. In that respect, World-Class Universities provide significant opportunities to raise knowledgeable, skilful, and virtuous individuals; and teach curricula with innovative pedagogical methods in order to produce highachieving graduates. Higher academic excellence of the university contributes to a better academic achievement of its graduates. The graduates of teacher education programmes are the candidates who will touch the lives of their students. They are also professionals who raise democratic, fair, and respectful students in order to be problem solvers, creative and critical thinkers, and generators of knowledge (International Society with Technology in Education [ISTE] Standards for Students, 2016). However, these graduates must primarily become better at using academic volitional strategies to improve academic achievement. 


\section{Significance of the Study}

Some studies in the related literature pointed out that self-regulatory efficiency (Fredricks et al., 2016; Ketonen et al., 2017; Langer \& Frie, 2017; Pekrun et al., 2004; Pekrun \& Stephens, 2012) and evidence of volitional control entail the use of volitional strategies or academic volitional strategies with utilization of experimental design studies (Chakraborty, 2016; Deimann, 2005; Dewitte \& Lens, 1999; Gollwitzer, 1996, 2012; Mokri, 2012; Tirri, 2011). On the other hand, Bergmann and Sams (2012) showed that flipping helped busy, vigorous and striving students, increased teacher-student and student-student interaction, and allowed for real differentiation of instruction. Generally, experimental techniques used in the quantitative research focused on volitional strategies in the related literature (McCann \& Garcia, 1999). On the other hand, some qualitative studies were conducted using the interview protocols. In some of these studies, volitional strategies addressed the effort and persistence during a goalstriving process (Hinnant-Crawford, Faison, \& Chang, 2016; Snow, Corno, \& Jackson, 1996). Pintrich (1999) stated that volition has become more dominant in educational representation of the learning process even if there was little knowledge available to apply volitional aspect in the context of learning.

Hence, the current study addressed the relationship between academic volitional strategies and undergraduate students' achievement in a flipped learning environment. The study shed light on the extent of undergraduate students' ability and use of academic volitional strategies related to achievement in the Turkish context. There has been little or no research on the relationship between academic volitional strategies and academic achievement in a flipped learning environment. This study sought to fill this gap.

\section{Purpose of the Study}

The purpose of this study was to examine whether there was a correlation between academic volitional strategies and academic achievement of the students from a teacher education programme who have experienced a flipped learning environment. The research question that guided this study was, "Is there a statistically significant correlation between academic volitional strategies and academic achievement of students in a flipped learning environment?". Therefore, the relationship between academic volitional strategies and student achievement in a flipped learning environment was examined in order to determine direction, form, and degree of the relationship.

\section{Related Literature Academic Volitional Strategies}

As an old variable, volition is defined as action taken to achieve one's goals. Historically, it grew out of the study of human motivation and action by William James in 1902 (Ach, 1910), and in order not to permit theoretical complexities. Thereby, 
volition was taken under the category of motivation. $\operatorname{Kuhl}(1984,1987)$ and Gollwitzer $(1996,1999)$ reintroduced it in a modern approach under action-control theory. In other words, volition is a conscious action (Clara, 2016; Vygotsky, 1987, p. 220) that generates from within where it encodes, stores, and performs independently without external effect. It is a kind of consciously self-generated reflection of cognitive states (Jeannerod, 2009). In other words, volition has supplementary power as to why individuals either continue regular exercise or refrain from doing so (Elsborg, Wikman, Nielsen, Tolver, \& Elbe, 2016). Therefore, it determines transition from intention to action (Broonen, 2010; Forstmeier \& Rüddel, 2008; Hikkerova, Ilouga, \& Sahut, 2016).

Volitional strategy directly leads to students' emotions. Several studies (Burić \& Sorić, 2012; Pekrun et al., 2004; Valle et al., 2003) reveal that, when they utilize volitional strategy efficiently, students are able to regulate emotion and motivation. Requirements maintaining the tendency of mediating goal attainments denote a volitional aspect to a goal-striving process. Volitional aspects represent facilitation of learning goals by protecting an individual's own desire to learn against disincentives to reach his/her objective (Cooper \& Corpus, 2009; McCann \& Garcia, 1999). Selfregulatory control skills are naturally constructed as volitional and are believed to have an indicative role in student achievement in school related tasks (McCann \& Turner, 2004; Mokri, 2012; Turner, Husman, \& Schallert, 2002; Turner \& McCann, 2000).

According to Corno and Kanfer (1993, p. 311), there are five categories of volitional control in an educational context. They are: metacognition, motivation, emotion and two environmental control strategies, i.e. control over the task situation and control over others in the task setting (p.312). Of these five categories, metacognition, motivation and environmental control received the most attention and are also considered as strategies for monitoring enthusiasm and feelings in academic contexts (Corno \& Kanfer, 1993; Deimann \& Bastiaens, 2010; Pekrun, 2000). These have been less-researched (McCann \& Garcia, 1999), and unique effects on intention to learn are worthy of research over goal outcomes (Corno, 1993, 2001; Wolters \& Rosenthal, 2000). During a troublesome school-related task completion, to keep their motivation, protect and increase their effort while facing difficulty or disincentives on the task, students use various volitional as well as cognitive and metacognitive strategies. Some incentives in the regulation of motivation and emotions include notes from Kuhl (1985), who suggests "reminding oneself of one's goals, providing rewards for finishing a proscribed amount of studying" (McCann \& Garcia, 1999, p. 262) and reflecting on the consequences of errors and mistakes are common responses given by students who react according to volitional strategies. By performing volitional strategies, learners have a better ability to strengthen their motivation and work towards their mission on academic tasks; and can complete assignments in a more timely and successful manner (Husman, McCann, \& Crowson, 2000; Molokoli, 2014). Wolters and Rosenthal (2000) state that learners' use of volitional strategies serves as one mechanism through 
which attitudes elucidate greater effort and perseverance at academic tasks in concert with cognition.

\section{Flipped Learning Environment}

With innovations in instructional technology and developments in active learning pedagogy, some educators encouraged implementing an intuitive educational model called flipped learning ("Flipped Learning 3.0"; Flipped Learning Global Initiative, 2017; Şahin \& Fell-Kurban, 2016). Flipped learning institutes a foundation in which learners grasp an individualized learning path appropriate for his/her individual needs (Bergmann \& Sams, 2012). Flipped learning includes asynchronous online lectures through which students learn outside the class and after that they meet with instructors, interact with them and their peers via in-class learning activities (Bergmann \& Sams, 2013; Bishop \& Verleger, 2013). In-class time is reserved for discovering, scaffolding and sharing ideas. The aim is to promote students' complex reasoning skills while engaging in intellectual and stimulating classroom experiences. While using flipped learning approach, students use their remembering and understanding skills that are lower level cognitive tasks before they come to class or in other words, their individual space. Then, they refer to higher-level cognitive skills such as analysis and creation among others in the classroom or in other words, in the group space (Karbach, 2014; Lee, Lim, \& Kim, 2017).

In flipped learning, which has become a global movement (Flipped Learning Academy, 2018; PRNewswire, 2018), instructors prepare course videos before the class so that knowledge transfers to students who watch the video. In addition, other course supporting materials such as journal assignments or discussion forums etc. are available through a digital online platform. Students who watch the flipped video come to in-class meetings with questions so they can activate their higher order thinking. Hence, instead of direct instruction, a dynamic classroom and interactive group learning space come into use (Knewton, 2015; Mok, 2014). In this respect, the instructor's role is to guide students as a facilitator and allow each student to apply the concepts, engage in subject matter, and internalize and develop the knowledge in class. Students can construct new knowledge by cooperation and discussion with peers (Bergmann \& Sams, 2012; Demiralay, 2014; Gencer, 2015).

The flipped learning approach also provides instructors at higher education institutions with opportunities to become all-inclusive of their students' learning styles. Flipping the classroom qualifies instructors to design and develop active learning experiences considering each student's needs (Berrett, 2012; McLaughlin et al., 2014). Most importantly, flipped learning is student-centred, which means that each student has the opportunity to realize self-discipline because all are obliged to come to class with the basic understanding of the learning attainments and the course materials provided by instructors. Having basic perceptions on learning outcomes, she/he can be fully active and engage in class discussion with higher-order perceptions. With the help 
of flipping, students can acquire the content in a self-paced manner and regulate the time and amount of content they view in the digital online platform. After this phase, instructors let their students engage with interactive learning experiences and be active partners in the learning ecosystem. Thereupon, these students can be challenged on their critical and creative thinking. In addition, instructors can provide feedback. Student success can be fostered by critical cognitive and metacognitive development and promoting advancements through cooperation with the help of providing rich open-ended experiences (Berrett, 2012; Bergmann \& Sams, 2012; McLaughlin et al., 2014). There are a number of research studies that measured student performance and perception (Lane-Kelso, 2015; Wasserman, Quint, Norris, \& Carr, 2017), sometimes in relation with self-efficacy and self-regulation context (Lai \& Hwang, 2016).

Since 2012, once flipping was coined, the flipped learning approach as pedagogy has been used in classrooms and instructors have searched for effectiveness via qualitative and quantitative paradigms (Birgili \& Fell-Kurban, 2017; Birgili, İler, \& Engin-Demir, 2016; Long, Cummins, \& Waugh, 2017; McKeown, 2016; Moffett, 2015; Moran \& Milsom, 2015; Redekopp \& Ragusa, 2013). The flipped approach has been examined through research and comprehensive theses (Files, 2016; Guggisberg, 2015; Saunders, 2014; Surakaya, 2015; Sun, 2015; Turan, 2015; Zuniga, 2015). However, understanding the relation between students' use of volitional strategies and their academic achievement in a flipped learning environment was a beginning, so these constructs were explored within the scope of this study.

\section{Methods}

\section{Research Design}

This exploratory study was based on a correlational or associational research design. In this research design, the relationship among two or more variables was studied without considering the effect of independent variable on the dependent one (Fraenkel, Wallen, \& Hyun, 2009). To this purpose, data were collected to determine the existence and degree of correlation between two or more quantifiable variables (Gay, Mills, \& Airasian, 2011). According to Fraenkel, Wallen, and Hyun (2009), correlational research in this regard was carried out to clarify the phenomena by identifying the relationship among the variables. Being an exploratory study, the discovery of the correlation between students' course achievement and the usage of academic volitional strategies can expand the understanding of these phenomena.

\section{Study Group}

Thirty-two undergraduate students participated in the study. They were enrolled in a teacher education programme at a university in Turkey, and had experienced education in a flipped learning environment. Of the 32, two were not included in the study as their results were not valid. According to participant descriptive statistics, the age of 30 students ( 3 males and 27 females) ranged from 19 to 43 years, and all of them 
were freshmen in the relevant academic semester. During one of their introductory courses in their teacher education programme, they learned the content area and basic teaching methods and techniques in that field.

\section{Data Collection Instrument}

The usage level of the students' academic volitional strategies was measured with Academic Volitional Strategies Inventory (AVSI) on a 5-point Likert-type scale (McCann \& Turner, 2004). The scale was composed of two parts; the first involved demographic information and the second involved 20 items regarding academic volitional strategies. Before data collection, the instrument was piloted in terms of intelligibility, length, and technical nature of the AVSI items. Cognitive interviews were conducted with some volunteer students from two different departments at the Faculty of Education. Cognitive interviewing (Willis, 1999) was applied to uncover the information hidden in AVSI. While exploring the inventory, the participants' thoughts and feelings were verbalized. This process had two types, namely "think aloud" (Ericsson \& Simon, 1990) and "verbal probing." Four volunteer respondents interpreted the items of AVSI via verbal probing questions. After the volunteers read the items aloud, they were asked to inquire whether there was anything difficult to understand. Then, length and technical structure of the items were assessed and discussed with the volunteers.

The instrument was composed of three sub-dimensions: self-efficacy enhancement (formed by nine items), negative-based incentives (formed by six items), and stress reducing actions (formed by five items). Reliability coefficient was grounded in its original version on a 30-item scale (McCann \& Garcia, 1999) and found to be $\alpha=.87$; for three subscale factors it was $\alpha=.82$ for self-efficacy enhancement, $\alpha=.73$ for negative-based incentives, and $\alpha=.69$ for stress reducing actions. The Cronbach's alpha reliability coefficient for the present study was $\alpha=.71$ in the AVSI total score, which indicated a moderate level of internal consistency for the scale with this specific sample (Cohen, 1988). In addition, pre- and post-test results supported the stability of the scale $(\mathrm{r}=.72 ; \mathrm{p}<.001)$. For example, "I remind myself that I usually do fine on exams and/or other assignments when I stick to a study schedule" (Item 2) was depicted by self-efficacy enhancement sub-scale whereas "I think about the possible negative consequences of doing poorly in this class" (Item 17) exemplified the negative-based incentives sub-scale. On the other hand, "If I am having difficulty, I call a friend from class and discuss the assignment/material with them" (Item 4) was given as an example for stress reducing actions sub-scale.

Convergent and divergent validity of AVSI were checked via Rosenberg's (1965) Self-Esteem Scale and the Deferment of Gratification Scale (Ray \& Najman, 1985). In addition, other instruments such as the Negative Mood Regulation Scale (Catanzaro \& Mearns, 1990) and Action Control Scale (Kuhl, 1994) were also compared with AVSI with regard to indicating students' tendencies for self-regulatory behaviours 
and other associated constructs (e.g., attention, initiative, impulse, discipline). The statistical results were not significant. It could be inferred that the selected scales could measure global focus on individual's characteristics whereas AVSI could measure a very narrow focus on academic situations depending on specific types of courses. In addition, another famous scale, Motivated Strategies for Learning Questionnaire (MSLQ) (Pintrich, Smith, Garcia, \& McKeachie, 1991) correlated with AVSI. A modest positive correlation between students' motivation and their learning efforts with volitional action was found in this study. This result showed that volition should be considered as a separate construct. However, for the sake of the validity construct, there seemed to be minimal overlap because of the fact that both instruments depended on a tendency toward self-regulatory behaviour. MSLQ Learning sub-scale also showed a distinction to AVSI, which means that items of AVSI were formed by independent factors, and measured distinct unique volitional self-regulatory strategies.

\section{Data Collection Process}

Ethical approval for the study was received before the data collection. Then, students' academic course achievement (their course grade) was collected through students' self-report after they looked at their transcripts at the end of the semester. The participants studying in a teacher education programme were freshman year students and experienced in flipped learning. They were supposed to study the content of the week and watch the flipped videos assigned by the instructor. In the course, they were also supposed to read articles or book chapters, to write journals and reflections on the assigned readings related with basic teaching methods and techniques. All the assignments were graded through an online system.

During the application of AVSI, the whole items were projected and read by the primary researcher. After the data collection process, items 4 and 17 were eliminated from the scale. The study was conducted, and preliminary analysis continued with the AVSI including 18 items.

\section{Data Analysis}

The current study aimed to answer the research question, "What is the relationship between academic volitional strategies and achievement of students from the Faculty of Education in a flipped learning environment?" In other words, the question "How strong is the correlation between academic volitional strategies and achievement of students in a flipped learning environment?" was explored by simple linear correlation analysis (Tabachnick \& Fidell, 2013) of the two variables. The first variable in this study is students' academic achievement. It is a predictor variable, continuous, and has interval measurement scale. The second variable are academic volitional strategy scores. It is a criterion variable, it is continuous, and has an interval measurement scale (see Table 1). The $\alpha$ level was set as .05 for statistical significance. Before running correlation analysis, normality assumptions were checked to determine the suitability 
of the analysis. Pearson correlation, which is a parametric statistical analysis, was employed due to non-violation of normality (Field, 2009).

Table 1

List of Variables in the Data File and Their Descriptions

\begin{tabular}{ll}
\hline Variable name & Description of the variables \\
\hline Achievement Score & Total grades from a course \\
AVSI Score & $\begin{array}{l}\text { Academic Volitional Strategies Inventory scores (1: I never do this; } 2: \text { I } \\
\text { sometimes do this; } 3: \text { Undecided; } 4: \text { I often do this; } 5: \text { I always do this) }\end{array}$
\end{tabular}

\section{Results}

In terms of descriptive and inferential statistics, the results presented in this section show whether there was any significant relationship between students' usage of academic volitional strategies and academic achievements in a flipped learning environment. In a preliminary examination of normality, the assumptions of random sampling and independent observation were satisfied. Skewness, kurtosis values, and histograms were checked on AVSI total, on its sub-dimensions, and course scores, in order to understand the variances and normality. Skewness and kurtosis values for each variable were between +3 and -3 , which satisfied less variation and less extreme cases in the data (Field, 2009). Still, histograms seem to present skewness visually. Especially academic volitional strategy scores and its sub-dimensions self-efficacy enhancement, negative-based incentives and stress-reducing actions, respectively - implied not having extreme cases and non-normality. In addition, Kolmogorov-Smirnov and Shapiro-Wilk were not significant for AVSI total scores ( $p>$.05). Similarly, it was not significant for achievement scores ( $p>.05)$. To conclude, normality assumption was confirmed by the obtained data.

In addition, descriptive analysis of students' academic achievement and academic volitional strategy scores are summarized in Table 2.

Table 2

Means, standard deviations for academic achievement and AVSI

\begin{tabular}{lcc}
\hline \multicolumn{1}{c}{ Variables } & $M$ & $S D$ \\
\hline Academic achievement & 87.73 & 12.58 \\
Predictor variable & & \\
AVSI & 62.61 & 9.80 \\
Self-efficacy enhancement & 30.55 & 4.96 \\
Negative-based incentives & 12.59 & 4.57 \\
Stress reducing actions & 12.27 & 3.22 \\
\hline
\end{tabular}


Table 3

Achievement score, AVSI and sub-dimensions of AVSI correlations

\begin{tabular}{lcccc}
\hline $\mathrm{N}=30$ & AVSI & Self-efficacy & $\begin{array}{c}\text { Negative-based } \\
\text { incentives }\end{array}$ & $\begin{array}{c}\text { Stress reducing } \\
\text { actions }\end{array}$ \\
\hline Achievement score & $.39^{*}$ & $.58^{* *}$ & -.13 & $.46^{* *}$ \\
Self-efficacy & $.85^{* *}$ & & & \\
$\begin{array}{l}\text { Negative-based } \\
\text { incentives }\end{array}$ & $.60^{*}$ & & & \\
Stress reducing actions & $.75^{* *}$ & & & \\
\hline
\end{tabular}

${ }^{*} p<.05 ;{ }^{* *} p<.01$

Furthermore, the results (Table 3 ) show a statistically significant relationship between AVSI scores and academic achievement of students in a flipped learning environment $(\mathrm{r}=.39, \mathrm{p}=.04<.05)$, according to Pearson product-moment correlations (Cohen, 1988). It means there was moderate correlation between achievement scores and academic volitional strategy scores. Similarly, the results of a one-step further analysis also revealed a significant association between academic achievement and the sub-dimensions of AVSI of self-efficacy enhancement $(\mathrm{r}=.58, \mathrm{p}<.01)$ and stress reducing actions $(\mathrm{r}=.46, \mathrm{p}<.01)$, but non-significant with negative-based incentives $(\mathrm{r}=-.13, \mathrm{p}>.01)$.

\section{Discussion}

This study explored the relationship between academic volitional strategies and students' achievements in a flipped learning environment by simple correlation analysis. The findings revealed that the students were more likely to have higher academic achievement on the course grade as their ability to use academic volitional strategy increased. This result supports some academic assumptions from related literature and is similar to previous research (Burić \& Sorić, 2012; Hinnant-Crawford et al., 2016; McCann \& Turner, 2004; Molokoli, 2014; Shepherd, 2006).

Burić and Sorić (2012) examined the relationships amongst 365 high school students' tests of emotions and academic achievement within the framework of the control-value theory. They found out that the students regulated their own emotion and motivation when they tended to use volitional strategies efficiently. Therefore, there is an indirect effect of regulation of emotions on cognitive engagement in academic studies, which may lead to a positive impact on academic achievement (McCann \& Turner, 2004). The current study also investigated the importance of academic volitional strategies and amount of their usage by students. It pointed out that the two sub-dimensions of AVSI, namely self-efficacy enhancement and stressreducing strategies, can be beneficial and effective for students' achievement during their higher education years. However, it should be noted that the sub-dimension "negative based incentives" might be damaging in their learning process. The results 
can be combined with some of the existing findings in relation to volitional control to provide new insights for further research. Some of the existing findings confirmed that volitional control education can have a positive effect on various motivational influences. Therefore, for many students, these influences have a positive relation with their cognitive engagement, which might affect their academic achievement (Garcia et al., 1998; Husman, McCann, \& Crowson, 2000; McCann \& Garcia, 1999).

On the other hand, the related literature discussed the academic volitional strategies in terms of their mediator roles (Corno \& Kanfer, 1993; Dewitte \& Lens, 2000; Garcia, McCann, Turner, \& Roska, 1998; Husman et al., 2000; Kuhl, 1985). For instance, McCann and Turner (2004) found that academic volitional strategies did not have a direct effect on students' course performance, which was measured by their course grade or end of semester grade. In addition, their path analysis results showed that academic volitional strategy might have direct effects on students' use of learning strategies measured by elaboration, critical thinking or rehearsal, among others. These results also illustrated indirect effects, which might reinforce the impact of some motivational factors on the usage of learning strategies. This study might have a prominent role in discussing the relationship between academic volitional strategies and course performance. In addition, the results of previous research pointed out a significant indirect effect of regulation on student achievement (Hinnant-Crawford et al., 2016). It was highlighted in Husman, McCann and Crowson's study (2000) that volition or volitional control has a mediator role in students' cognition in academic task-related situations, because volitional control is an ability to use strategies to advocate and protect motivation among various course tasks in order to attain one's academic goals. Additionally, the study addressed action control strategies to mediate the relation between an effort to learn and an opportunity of this success or attainment related behaviour. This comment is related to the fact that volitional strategies should be examined as a mediator (Dewitte \& Lens, 2000). Dafna and Haieman's (2005) research findings revealed that older students learned coping techniques much better in school related tasks. These findings are also supported by Corno's (2004) assumption that college students tended to use academic volitional strategies more frequently.

The study result is also compatible with Molokoli's study (2014) in which the group consisted of 150 ninth grade learners in two different public secondary schools situated in Rustenburg district of the North West province in South Africa. The purpose of the study was to develop, implement and evaluate a model in order to enhance a learner's volitional strategy use to augment teaching and learning achievement. Pre-, postand retention test results showed that six volitional strategies; for example, planning, volition, self-efficacy, self-control pressure, intention monitoring etc., contributed to high performance. High-performing students are better in controlling their emotions and reactions during failure. This is in line with the finding of the current study that the more students make use of stress reducing actions and self-efficacy enhancement, the higher are the scores they achieve in the course. 


\section{Conclusions}

The current study was used to explore the relationship between academic volitional strategies and students' academic achievement in a flipped learning environment at a university in Turkey. The study found a significant moderate relationship between students' achievement and AVSI scores. It can be concluded that the students exposed to a flipped learning approach regulate their emotion and motivation toward course assignments to enhance learning goals. In this research, the study group was involved in a very comprehensive course. From the very beginning of the semester until the end, they studied national curriculum content and basic teaching methods and techniques in the field. They found daily examples related with the content from national and international resources, wrote journals and reflections regarding the experience and content of the week. With these experiences, the students became adaptive and were able to enhance their self-efficacy beliefs. They could be better at reassuring themselves about the importance of an assignment, exam, and paper, and then warn themselves to concentrate on those items. They motivate themselves by saying "you can do this!" and keep their effort when they stick to a study schedule by reminding themselves they usually do fine on exams or assignments. Moreover, the students who have had flipped learning experiences seem to be able to find creative ways of making their work efforts more appealing during the time they study (McCann \& Garcia, 1999). When they have difficulty, they prefer to discuss the assignment or material with the help of a friend, an activity that is allowed. Some are able to use methods of relaxation to concentrate better on studies. These strategies showed that the better the students used these volitional strategies in their course, the higher their academic achievement became in that course.

We should take into consideration that volitional strategies vary across learners and they can be taught to use a multitude of approaches. However, volitional strategies cannot be taught by short-term instruction (Corno, 2004). The students should internalize academic rules, take responsibility, and learn to deal with the increased complexities of academic achievement. How a teacher motivates students by getting their attention, presenting the content, or helping them to present the content is of the utmost importance. It builds student confidence levels and achievement, which contributes to increased satisfaction.

\section{Limitations, Implications and Suggestions for Further Research}

This study can be conducted with different samples of students with different majors at the Faculty of Education and in different settings. As a longitudinal study, the same group of students might be followed in terms of their academic volitional strategy progress. Moreover, this is a quantitative study that can be examined through a mixed method design (Tashakkori \& Teddlie, 1998). The effect of academic volitional strategies on achievement can also be explored via an experimental-control condition. For further research, the current study can be redesigned by using extended data 
with more participants. Some variables such as different characteristics of students or different learning environments could be selected for checking their impact on the association between academic volitional strategies and academic achievements. Among recommendations for higher educational institutions, as instructors, we should support our students' ability to develop their academic study habits that can contribute to their achievement. Thereby, students would gain the ability to regulate their learning activities, and develop positive work habits when they are dealing with the complexities of academic assignments.

As practitioners, we know that a flipped learning environment may promote students' reflection and peer group interaction. We recommend that volitional control strategy techniques be used by the instructors aiming to promote their students' effective work habits without them procrastinating in the course of their studies. They should instruct the students how to think positively when finishing a task, and to appreciate the value of the assignments.

\section{References}

Ach, N. (1910). Über den Willensakt und das Temperament [On the act of will and the temperament]. Leipzig: Quelle \& Meyer.

Bandura, A. (1986). Social foundations of thought and action: A social-cognitive theory. Upper Saddle River, NJ: Prentice-Hall.

Bembenutty, H. (2009). Academic delay of gratification, self-regulation of learning, gender differences and expectancy value. Personality and Individual Differences, 46(1), 347-352. https://doi.org/10.1016/j.paid.2008.10.028

Bergmann, J., \& Sams, A. (2012). Flip your classroom: Reach every student in every class every day. ISTE: International Society for Technology in Education.

Bergmann, J., \& Sams, A. (2013). Flipping for mastery. Educational Leadership, 71(4), 24-29.

Berrett, D. (2012). How 'flipping' the classroom can improve the traditional lecture?. A guide to the flipped classroom. The Chronicle of Higher Education, 1-14. Retrieved from https:// www.chronicle.com/article/How-Flipping-the-Classroom/130857

Birgili, B., \& Fell-Kurban, C. (2017, June). Evaluation of a flipped course by using illuminative model. Paper presented at $3^{\text {rd }}$ European Conference on Curriculum Studies, University of Stirling, Scotland, UK.

Birgili, B., İler, C., \& Engin-Demir, C. (2016, October). Flipped learning approach in a private university: A needs-assessment study. Paper presented at $4^{\text {th }}$ International Conference on Curriculum and Instruction, Belek-Antalya, Turkey.

Bishop, J. L., \& Verleger, M. A. (2013). The flipped classroom: A survey of the research. Paper presented at 120th ASEE Annual Conference \& Exposition, Atlanta, GA.

Broonen, J. P. (2010). From intentions to actions: Volition in vocational counseling. Orientation Scolarie at Professionnalle, 39, 137-171. https://doi.org/10.4000/osp.2493 
Burić, I., \& Sorić, I. (2012). The role of test hope and hopelessness in self-regulated learning: Relations between volitional strategies, cognitive appraisals and academic achievement. Learning and Individual Differences, 22(4), 523-529. https://doi.org/10.1016/j. lindif.2012.03.011

Catanzaro, S. J., \& Mearns, J. (1990). Measuring generalized expectancies for negative mood regulation: Initial scale development and implications. Journal of Personality Assessment, 54(3-4), 546-563. https://doi.org/10.1207/s15327752jpa5403\&4 11

Chakraborty, R. (2016, January-February). A study on the combined correlation between academic delay of gratification and academic volition, with emotional intelligence in student teachers. International Journal of Novel Research in Education and Learning, 3(1), 17-24.

Clarà, M. (2016). How instruction influences conceptual development: Vygotsky's theory revisited. Educational Psychologist, 52(1), 50-62. https://doi.org/10.1080/00461520.2016 .1221765

Cohen, J. (1988). Statistical Power Analysis for the Behavioral Sciences ( $2^{\text {nd }}$ ed.) Hillsdale, NJ: Erlbaum.

Cooper, C. A., \& Corpus, J. H. (2009). Learners' developing knowledge of strategies for regulating motivation. Journal of Applied Developmental Psychology, 30(4), 525-536. https:// doi.org/10.1016/j.appdev.2008.12.032

Corno, L. (1993). The best-laid plans: Modern conceptions of volition and educational research. Educational Researcher, 22(2), 14-22. https://doi.org/10.3102/0013189X022002014

Corno, L. (May, 2001). Volitional aspects of self-regulated learning. In B. J. Zimmerman, \& D. H. Schunk (Eds.), Self-regulated learning and academic achievement: Theoretical perspectives $\left(2^{\text {nd }}\right.$ ed.). Manwah, New Jersey: Taylor \& Francis.

Corno, L. (2004). Introduction to the special issue. Work habits and work styles: volition in education. Teachers College Record, 106(9), 1669-1694. https://doi.org/10.1111/j.14679620.2004.00400.x

Corno, L., \& Kanfer, R. (1993). The role of volition in learning and performance. Review of Research in Education, 19(1), 301-341. https://doi.org/10.2307/1167345

Dafna, K., \& Haieman, T. (2005). Task-oriented versus emotion-oriented coping strategies: The case of college students. College Student Journal, 39(1), 72-85.

Deimann, M. (2005). Effects of Distributed Versus Integrated Motivational and Volitional Strategies on Learner Attitudes and Performance. (Unpublished Doctoral Dissertation). Germany: Erfurt University.

Deimann, M., \& Bastiaens, T. (2010). The role of volition in distance education: An exploration of its capacities. The International Review of Research in Open and Distance Learning, 11(1), 1-16. https://doi.org/10.19173/irrodl.v11i1.778

Demiralay, R. (2014). Evde ders okulda ödev modelinin benimsenmesi sürecininyeniliğin yayilimi kurami çerçevesinde incelenmesi [Examining the process of Flipped classroom model acceptance in the context of diffusion of innovations theory]. (Doctoral Dissertation). Turkey: Faculty of Education, Gazi University, Ankara.

Dewitte, S., \& Lens, W. (1999). Volition: Use with measure. Learning and Individual Differences, 11(3), 321-333. https://doi.org/10.1016/S1041-6080(99)80006-5 
Dewitte, S., \& Lens, W. (2000). Exploring volitional problems in procrastinators. The International Journal of Educational Research, 33(7-8), 733-75. https://doi.org/10.1016/ S0883-0355(00)00047-1

Elsborg, P., Wikman, J. M., Nielsen, G., Tolver, A., \& Elbe, A.-M. (2016). Development and initial validation of the volition in exercise questionnaire (VEQ). Measurement in Physical Education and Exercise Science, 21(2), 57-68. https://doi. org/10.1080/1091367X.2016.1251436

Ericsson, K. A., \& Simon, H. A. (1990). Verbal reports as data. Psychological Review, 87(3), 215-250. https://doi.org/10.1037/0033-295X.87.3.215

Ferreira, F. H., \& Gignoux, J. (2010). Eğitimde fırsat eşitsizliği: Türkiye örneği [Inequality of opportunity in education: Turkish example]. Türkiye Cumhuriyeti DPT ve Dünya Bankası Refah ve Sosyal Politika Analitik Çalışma Programı [The Republic of Turkey State Planning Organization and World Bank Social Politics Analytical Work Program] (DPT-World Bank Report No: 4). Retrieved from World Bank website: http://siteresources.worldbank.org/ INTTURKEYINTURKISH/147254-1269017398324/22764932/EgitimdeFirsatEsitsizligi. pdf.

Field, A. (2009). Discovering statistics using SPSS (3 ${ }^{\text {rd }}$ ed.). London: Sage.

Files, D. D. (2016). Instructional approach and mathematics achievement: An investigation of traditional, online, and flipped classrooms in college algebra. (Doctoral Dissertation). USA: Florida Institute of Technology.

Flipped Learning Academy (2018). Higher Education Flipped Learning Conference. Retrieved from http://www.flippedlearningacademy.org

Flipped Learning Global Initiative (2017). Flipped Learning: A Global Movement. Retrieved from http://flglobal.org

Forstmeier, S., \& Rüddel, H. (2008). Measuring volitional competences: Psychometric properties of a short form of the Volitional Components Questionnaire (VCQ) in a clinical sample. The Open Psychology Journal, 1, 66-77. https://doi. org/10.2174/1874350100801010066

Fraenkel, J., Wallen, N., \& Hyun, H. (2012). How to design and evaluate research in education ( $7^{\text {th }}$ ed.). New York, NY: McGraw Hill.

Fredricks, J. A., Filsecker, M., \& Lawson, M.A. (2016). Student engagement, context, and adjustment: Addressing definitional, measurement, and methodological issues. Learning and Instruction, 43(1), 1-4. https://doi.org/10.1016/j.learninstruc.2016.02.002

Garcia, T., McCann, E. J., Turner, J. E., \& Roska, L. (1998). Modeling the mediating role of volition in the learning process. Contemporary Educational Psychology, 23(4), 392-418. https://doi.org/10.1006/ceps.1998.0982

Gay, L. R., Mills, G. E., \& Airasian, P.W. (2011). Educational research competencies for analysis and applications $\left(10^{\text {th }}\right.$ ed.). New Jersey, NJ: Pearson.

Gencer, B. G. (2015). Okullarda ters-yüz sınıf modelinin uygulanmasına yönelik bir vaka çalışması [A case study towards the implementation of the flipped classroom model in the schools]. (Master's Thesis). Turkey: Bahçeşehir University, Istanbul.

Gollwitzer, P. M. (1996). The volitional benefits of planning. In P. M. Gollwitzer, \& J. A. Bargh (Eds.), The psychology of action. Linking cognition and motivation to behavior (pp. 287-312). New York, NY: Guilford Press. 
Gollwitzer, P. M. (1999). Implementation intentions. Strong effects of simple plans. American Psychologist, 54(7), 493-503. https://doi.org/10.1037/0003-066X.54.7.493

Gollwitzer, P. M. (2012). Mindset theory of action phases. In P. A. M. Van Lange, A. W. Kruglanski, \& E. T. Higgins (Eds.), Theories of social psychology (pp. 526-545). Thousand Oaks, CA: Sage. https://doi.org/10.4135/9781446249215.n26

Guggisberg, L. S. (2015). Student perceptions of digital resources and digital technology in a flipped classroom. (Doctoral Dissertation). USA: Educational Leadership, University of North Dakota, Grad Forks, North Dakota.

Hikkerova, L., Ilouga, S. N., \& Sahut, J. M. (2016). The entrepreneurship process and the model of volition. Journal of Business Research, 69, 1868-1873. https://doi.org/10.1016/j. jbusres.2015.10.071

Hinnant-Crawford, B. N., Faison, M. Z., \& Chang, M. L. (2016). Culture as mediator. Journal for Multicultural Education, 10(3), 274 - 293. https://doi.org/10.1108/JME-05-2016-0032

Husman, J., McCann, E., \& Crowson, H. M. (2000). Volitional strategies and future time perspective: Embracing the complexity of dynamic interactions. International Journal of Educational Research, 33(7-8), 777-799. https://doi.org/10.1016/S0883-0355(00)00050-1

International Society with Technology in Education [ISTE] Standards for Students (2016). Promote Future-ready Learning with the ISTE Standards for Students. Retrieved from https:// www.iste.org/standards/standards/for-students

Jeannerod, M. (2009). Neuroscience of volition and action. Encyclopedia of Consciousness, 1, 111-120. https://doi.org/10.1016/B978-012373873-8.00084-0

Karbach, M. (2014). Flipped Classroom Visually Explained for Students. Retrieved from http:// www.educatorstechnology.com

Ketonen, E. E., Dietrich, J., Moeller, J., Salmela-Aro, K., \& Lonka, K. (2017, In Press). The role of daily autonomous and controlled educational goals in students' academic emotion states: An experience sampling method approach. Learning and Instruction, 53, 1-11.

Knewton (2015). Flipped, tipped or traditional: Adaptive technology can support any blended learning model. Retrieved from https://www.knewton.com/tag/flipped-classroom

Kuhl, J. (1984). Volitional aspects of achievement motivation and learned helplessness: Toward a comprehensive theory of action control. In B. A. Maher, \& W. B. Maher (Eds.), Progress in Experimental Personality Research (pp. 101-171). Orlando, FL: Academic Press.

Kuhl, J. (1985). Volitional Mediators of Cognition-behavior Consistency: Self-regulatory Processes and Action Versus State Orientation. In J. Kuhl, \& J. Beckmann (Eds.), Action control: From cognition to behavior (pp. 101-128). Berlin, Germany: Springer-Verlag. https://doi.org/10.1007/978-3-642-69746-3 6

Kuhl, J. (1987). Action control: The maintenance of motivational states. In F. Halisch, \& J. Kuhl (Eds.), Motivation, Intention and Volition (pp. 279-291). Berlin, Germany: Springer. https://doi.org/10.1007/978-3-642-70967-8 19

Kuhl, J. (1994). A Theory of Action and State Orientation. In J. Kuhl, \& J. Beckmann (Eds.), Volition and personality: Action versus state orientation (pp. 9-46). Gottingen, Germany: Hogrefe \& Huber. 
Lai, C.-L., \& Hwang, G.-J. (2016). A self-regulated flipped classroom approach to improving students' learning performance in a mathematics course. Computers \& Education, 100, 126140. https://doi.org/10.1016/j.compedu.2016.05.006

Lane-Kelso, M. (2015). The pedagogy of flipped instruction in Oman. The Turkish Online Journal of Educational Technology, 14(1), 143-150.

Langer, K., Frie, M., \& Bohn-Gettler, C. (2017, April). Emotion, text difficulty, and purpose for reading: How factors influence reading comprehension. Poster presented at Celebrating Scholarship \& Creativity Day, 131. Retrieved from https://digitalcommons.csbsju.edu/ elce cscday/131

Lee, J., Lim, C., \& Kim, H. (2017). Development of an instructional design model for flipped learning in higher education. Education Technology Research and Development, 65, 427453. https://doi.org/10.1007/s11423-016-9502-1

Long, T., Cummins, J., \& Waugh, M. (2017). Use of the flipped classroom instructional model in higher education: instructors' perspectives. Journal of Computing in Higher Education, 29(2), 179-200. https://doi.org/10.1007/s12528-016-9119-8

Madden, J., Lynch, D., \& Doe, T. (2015). Teacher researchers: Creating the outstanding school. London, UK: Primrose Hall Publishing Group.

McCann, E. J., \& Garcia, T. (1999). Maintaining motivation and regulating emotion: Measuring individual differences in academic volitional strategies. Learning and Individual Differences, 11(3), 259-279. https://doi.org/10.1016/S1041-6080(99)80003-X

McCann, E. J., \& Turner, J. E. (2004). Increasing student learning through volitional control. Teachers College Record, 106(9), 1695- 1714. https://doi.org/10.1111/j.14679620.2004.00401.x

McKeown, J. (2016). From "sage on the stage to guide on the side": A case study of a transition to flipped English language learning in a higher education setting in Turkey. International Association of Research in Foreign Language Education and Applied Linguistics ELT Research Journal, 5(2), 145-154.

McLaughlin, J. E., Roth, M. T., Glatt, D. M., Gharkholonarehe, N., Christopher A. Davidson, C. A., Griffin, L. M., Esserman, D. A., \& Mumper, R. J. (2014). The flipped classroom: A course redesign to foster learning and engagement in a health professions schools. Academic Medicine, 89(2), 236-243. https://doi.org/10.1097/ACM.0000000000000086

McMahon, M., \& Luca, J. (2001). Assessing student's self-regulatory skills. In Meeting at the crossroads. Proceedings of the 18th Annual Conference of the Australasian Society for Computers in Learning in Tertiary Education. Melbourne, Australia, 9-12 December.

Moffett, J. (2015). Twelve tips for "flipping" the classroom. Medical Teacher, 37(4), 33-336. https://doi.org/10.3109/0142159X.2014.943710

Mok, H. N. (2014). Teaching tip: The flipped classroom. Journal of Information Systems Education, 25(1), 7-11.

Mokri, P. (2012). Developing and validating an instrument to measure academic self-regulation. (Doctoral Dissertation). USA: Virginia Polytechnic Institute and State University, Blacksburg, VA.

Molokoli, D. L. (2014). A model for enhancing volitional strategies' use and mathematics achievement in Grade 9 in a rural community school. (Doctoral Dissertation). South Africa: Potchefstroom Campus of the North-West University. 
Moran, K., \& Milsom, A. (2015). The flipped classroom in counselor education. Counselor Education \& Supervision, 54, 32-43. https://doi.org/10.1002/j.1556-6978.2015.00068.x

Ouellet, K. (2017). Experimenting with low threshold, high ceiling mathematics tasks in a Grade 10 mathematics class: a mixed method study on student engagement. (Master's Thesis). Canada: Queen's University in Kingston, Ontario.

Pekrun, R. (2000). A Social-cognitive, Control-value Theory of Achievement Emotions. In J. Heckhausen (Ed.), Motivational psychology of human development (pp. 143-163). Amsterdam: Elsevier. https://doi.org/10.1016/S0166-4115(00)80010-2

Pekrun, R., Goetz, T., Perry, R. P., Kramer, K., Hochstadt, M., \& Molfenter, S. (2004). Beyond test anxiety: Development and validation of the test emotions questionnaire (TEQ). Anxiety, Stress, and Coping, 17(3), 287-316. https://doi.org/10.1080/1061580041233130 $\underline{3847}$

Pekrun, R., \& Stephens, E. J. (2012). Academic emotions. In K. R. Harris, S. Graham, T. Urdan, S. Graham, J. M. Royer, \& M. Zeidner, (Eds.), APA educational psychology handbook, Vol. 2: Individual differences and cultural and contextual factors (pp. 3-31). Washington, DC: American Psychological Association.

Pintrich, P. R. (1999). Taking control of research on volitional control: Challenges for future theory and research. Learning and Individual Differences, 11(3), 335-354. https://doi. org/10.1016/S1041-6080(99)80007-7

Pintrich, P. R., Smith, D. A., Garcia, T., \& McKeachie, W. J. (1991). A manual for the use of the motivated strategies questionnaire (MSLQ). Ann Arbor: University of Michigan, National Center for Research to Improve Postsecondary Teaching and Learning.

PRNewswire (2018). Flipped Learning Global Initiative Collaborates with Pioneers from Harvard, Stanford, and MEF University on International Standards for Flipped Training. Retrieved from https://www.prnewswire.com/news-releases/flipped-learning-globalinitiative-collaborates-with-pioneers-from-harvard-stanford-and-mef-university-oninternational-standards-for-flipped-training-300592917.html

Ray, J. J., \& Najman, J. M. (1985). The generalizability of deferment of gratification. Journal of Social Psychology, 126(1), 117-119. https://doi.org/10.1080/00224545.1986.9713578

Redekopp, M. W., \& Ragusa, G. (2013, June). Evaluating flipped classroom strategies and tools for computer engineering. Paper presented at $120^{\text {th }}$ ASEE Annual Conference \& Exposition, Atlanta, USA.

Rosenberg, M. (1965). Society and the adolescent self-image. Princeton, NJ: Princeton University Press. https://doi.org/10.1515/9781400876136

Saunders, J. M. (2014). The flipped classroom: its effect on student academic achievement and critical thinking skills in high school mathematics. (Doctoral Dissertation). USA: Liberty University, Lynchburg, VA.

Shepherd, R. M. (2006). Volitional strategies and social anxiety among college students. College Quarterly, 9(4), 1-12.

Sırakaya, D. (2015). Tersyüz sinif modelinin akademik başari, öz-yönetimli öğrenme hazirbulunuşluğu ve motivasyon üzerine etkisi [The effect of flipped classroom model on academic achievement, self-directed learning readiness and motivation]. (Doctoral Dissertation). Turkey: Faculty of Education, Gazi University, Ankara. 
Snow, R. E., Corno, L., \& Jackson, D. (1996). Individual Differences in Affective and Cognitive Functions. In D. C. Berliner, \& R. C. Calfee (Eds.), Handbook of Educational Psychology (pp. 243-310). New York, NY: Prentice Hall.

Sun, Z. (2015). The role of self-regulation on students'learning in an undergraduate flipped math class. (Doctoral Dissertation). USA: Ohio State University, EDU Policy and Leadership.

Şahin, M., \& Fell-Kurban, K. (2016). The Flipped Approach to Higher Education: Designing Universities for Today's Knowledge Economies and Societies. Bingley, UK: Emerald Publishing. https://doi.org/10.1108/S2059-2841201603

Tabachnick, B. G., \& Fidell, L. S. (2013). Using multivariate statistics. Needham Heights, MA: Allyn and Bacon.

Tashakkori, A., \& Teddlie, C. (1998). Mixed methodology: Combining qualitative and quantitative approaches. Thousand Oaks, CA: Sage.

Tirri, K. (2011). Holistic school pedagogy and values: Finnish teachers' and pupils' perspectives. International Journal of Educational Research, 50(2), 159-165. https://doi. org/10.1016/j.ijer.2011.07.010

Turan, Z. (2015). Ters yüz sınıf yönetiminin değerlendirilmesi ve akademik başarı, bilişsel yük ve motivasyona etkisinin incelenmesi [The evaluation of flipped classroom method and examination of its effects on academic achievement, cognitive load and motivation]. (Doctoral Dissertation). Turkey: Atatürk University, Erzurum.

Turner, J. E., Husman, J., \& Schallert, D. L. (2002). The importance of students' goals in their emotional experience of academic failure: Investigating the precursors and consequences of shame. Educational Psychologist, 37(2), 79-89. https://doi.org/10.1207/ $\underline{\text { S15326985EP3702 } 3}$

Turner, J. E., \& McCann, E. J. (2000, April). The importance of student goals and academic context: Investigating the consequences of experiencing shame upon students' subsequent motivational behavior, volitional strategy use, and academic achievement. Paper presented at the Annual Meeting of the American Educational Research Association. LA: New Orleans.

Valle, A., Cabanch, R. G., Nunez, J. C., Gonzáles-Pienda, J., Rodriguez, S., \& Pineiro, I. (2003). Cognitive, motivational, and volitional dimensions of learning: An empirical test of a hypothetical model. Research in Higher Education, 44(5), 557- 580. https://doi. org/10.1023/A:1025443325499

Vygotsky, L. S. (1987). Thinking and speech (N. Minick, Trans.). In R. W. Rieber, \& A. S. Carton (Eds.), The collected works of L. S. Vygotsky. Volume 1: Problems of general psychology (pp. 39-285). New York, NY: Plenum Press.

Wasserman, N. H., Quint, C., Norris, S. A., \& Carr, T. (2017). Exploring Flipped Classroom Instruction in Calculus III. International Journal of Science and Mathematics Education, 15(3), 545-568. https://doi.org/10.1007/s10763-015-9704-8

Willis, G. B. (1999). Cognitive interviewing: A "How To" guide. Meeting of the American Statistical Association.

Wolters, C. A., \& Rosenthal, H. (2000). The relation between students' motivational beliefs and their use of motivational regulation strategies. International Journal of Educational Research, 33(7-8), 801-820. https://doi.org/10.1016/S0883-0355(00)00051-3 
Zimmerman, B. J. (1990). Self-regulating academic learning and achievement: The emergence of a social cognitive perspective. Educational Psychology Review, 2(2), 173-201. https:// doi.org/10.1007/BF01322178

Zuniga, R. R. (2015). Enhancing academic achievement and satisfaction by flipping the teacher preparation classroom. (Doctoral Dissertation). USA: The University of Texas at Brownsville.

\section{Bengi Birgili}

MEF University, Faculty of Education,

Department of Mathematics and Science Education

Maslak Ayazağa street No:4 34396 Maslak-Sarıyer, Istanbul, Turkey

birgilib@mef.edu.tr

\section{Fatma Nevra Seggie}

Boğaziçi University, Faculty of Education,

Department of Educational Sciences

North Campus 34342 Bebek, Istanbul, Turkey

nevra.seggie@boun.edu.tr

\section{Zeynep Kızıltepe}

Boğaziçi University, Faculty of Education, Department of Educational Sciences

North Campus 34342 Bebek, Istanbul, Turkey

zeynep.kiziltepe@boun.edu.tr 


\section{Istraživanje odnosa voljnih strategija i akademskog postignuća u „obrnutoj učionici"}

\section{Sažetak}

Ova studija provedena je kako bi se utvrdilo postojanje veze izmedu akademskih voljnih strategija i akademskog postignuća u'obrnutoj učionici'. Akademsko postignuće podrazumijeva okolinu u kojoj studenti pokazuju samodisciplinu na nastavnim zadatcima. Studenti mogu povećati angažman tijekom akademskih zadataka koristeći se voljnim strategijama te ih učinkovitije izvršiti. Sudionici istraživanja bili su dodiplomski studenti upisani u program obrazovanja budućih učitelja na instituciji visokog obrazovanja u Turskoj. Na toj skupini studenata primijenjen je Upitnik akademskih voljnih strategija (AVSI) unutarnje konzistentnosti $\alpha=, 8$. Dobiveni podatci istraženi su Pearsonovom korelacijom. Rezultati pokazuju statistički pozitivan odnos izmedu AVSI rezultata i akademskih postignuća $(r=, 39, p=<, 05)$. Stoga voljne vještine i akademska postignuća djeluju zajedno u programu obrazovanja učitelja.

Ključne riječi: korelacijska studija; obrnuto učenje; visoko obrazovanje; obrazovanje učitelja; samoregulirano učenje.

\section{Uvod}

Nekoliko aspekata vezanih uz predmetno područje definira postignuće. Općenito je to uspješno dosezanje ciljanog stadija trudom, vještinom i hrabrošću. Postignuće školskog uspjeha zahtijeva okolinu u kojoj učenici trebaju pokazivati samodisciplinu pri izvršavanju školskih dužnosti. Drugim riječima, samodisciplina je preduvjet koji učenici trebaju zadovoljiti kako bi se angažirali u zadatcima vezanima uz školu i razvili radne navike. To vodi do uspješnog ispunjenja školskih izazova. Stoga se te pozitivne navike mogu povezati sa samoregulativnim ponašanjem učenika, tj. studenata (Bandura, 1986; Bembenutty, 2009; Pekrun i sur., 2004). Što je veće upravljanje okolinom učenja, bolja je učenička koncentracija na akademske zadatke (Burić i Sorić, 2012; McCann i Turner, 2004). Dodatno, zadržavanje motivacije i reguliranje emocija važni su aspekti za akademsku izvedbu studenata. Pozitivni obrazovni ishodi izviru iz količine učeničkog angažmana na samoregulacijskim aktivnostima. Te samoupravljačke vještine također 
se aktiviraju kada pojedinci preuzimaju odgovornost, kada su otvoreni za učenje, aktivno i metakognitivno motivirani (Cooper i Corpus, 2009; Fredricks, Filsecker i Lawson, 2016; Zimmerman, 1990). Pekrun (2000) tvrdi da aktivacija pozitivnih osjećaja, odnosno "vjere u uspješnost" ili "uživanja u učenju” doprinosi revnosti za učenjem i usredotočenim interesom na zadatak. Ta motivacija vodi primjeni nekoliko strategija učenja koje rezultiraju postignućem u tom procesu (Ketonen, Dietrich, Moeller, Salmela-Aro i Lonka, 2017; Ouellet, 2017; Pekrun i Stephens, 2012).

U novijim istraživanjima samoregulirane aktivnosti povezuju se $s$ teorijom procesuiranja informacija koja ukazuje na elaboraciju, organizaciju i vježbu, a u kojima su upotreba metakognitivnih i kognitivnih vještina u primarnom fokusu. Ipak, novije studije utvrdile su sklonost ideji da samoregulacija povećava kontinuirano nastojanje i ustrajnost učenika na obavezama (Langer, Frie i Bohn-Gettler, 2017; Madden, Lynch i Doe, 2015; McMahon i Luca, 2001; Shepherd, 2006). Naime, samousmjerenost, trud i izdržljivost ili ustrajnost pri postizanju cilja smatraju se važnim konstruktima samoregulacijske kontrole (McCann i Garcia, 1999). Pažnja i ustrajnost pri postizanju cilja smatraju se preduvjetima za pozitivne ishode učenja, uspjeh i postignuće.

Turska je suočena s borbom protiv nejednakosti u obrazovnim prilikama (Ferreira i Gignoux, 2010). Mnoge su nesuglasnosti u postignućima na rezultatima međunarodnih ispita visokog rizika. Studije pokazuju da učenici nemaju dostatno znanje, vještine ni sklonosti koji su u skladu s onima koje se zahtijevaju u 21. stoljeću. Ipak, oni će biti građani društva odgovorni za oblikovanje budućnosti. Stoga bi kao praktičari trebali znati više o načinu na koji možemo unaprijediti alate i metode obrazovnog sustava. $U$ tom pogledu sveučilišta svjetske klase pružaju značajne prilike za odgoj obrazovanih, vještih i čestitih pojedinaca. Kako bi spomenute institucije stvarale diplomce s visokom razinom postignuća, također bi trebale podučavati kurikule koji uključuju inovativne pedagoške metode. Što je viša akademska izvrsnost sveučilišta, to je akademsko postignuće diplomaca veće. Diplomci programa za obrazovanje učitelja oni su koji će dotaknuti živote svojih učenika. Također su stručnjaci koji odgajaju demokratične, poštene i uljudne učenike koji će rješavati probleme, koristili kse reativnim i kritičkim mišljenjem te stvarati znanje (International Society with Technology in Education [ISTE] Standards for Students, 2016). Međutim, isprva ti diplomci moraju biti bolji u primjeni akademskih voljnih strategija za unapređenje akademskog postignuća.

\section{Važnost istraživanja}

Neke su studije u srodnoj literaturi istaknule da samoregualcijska učinkovitost (Fredricks i sur., 2016; Ketonen i sur., 2017; Langer i Frie, 2017; Pekrun i sur., 2004; Pekrun i Stephens, 2012) i dokazi voljne kontrole obuhvaćaju upotrebu voljnih strategija ili akademskih voljnih strategija, uz primjenu studija eksperimentalnog dizajna (Chakraborty, 2016; Deimann, 2005; Dewitte i Lens, 1999; Gollwitzer, 1996, 2012; Mokri, 2012; Tirri, 2011). S druge strane, Bergmann i Sams (2012) su pokazali da okretanje pomaže vrijednim, energičnim i motiviranim učenicima; 
povećava interakciju između učitelja i učenika, učenika i učenika; pruža priliku istinske diferencijacije nastave. Općenito, eksperimentalne tehnike primijenjene $\mathrm{u}$ kvantitativnom istraživanju usredotočile su se na voljne strategije u vezanoj literaturi (McCann i Garcia, 1999). S druge strane, neke kvalitativne studije provedene su uz upotrebu protokola intervjua. $U$ nekima su se od tih studija voljne strategije odnosile na angažman i ustrajnost tijekom procesa postizanja cilja (Hinnant-Crawford, Faison, i Chang, 2016; Snow, Corno, i Jackson, 1996). Pintrich (1999) je istaknuo da volja postaje dominantnija u obrazovnom predstavljanju procesa učenja, čak i ako nema puno dostupnog znanja za primjenu voljnog aspekta u kontekstu učenja.

Stoga ovo istraživanje ispituje odnos između akademskih voljnih strategija i postignuća dodiplomskih studenata u obrnutom okruženju za učenje. Ova je studija osvijetlila doseg sposobnosti dodiplomskih studenata i primjenu akademskih voljnih strategija povezanih s postignućem u kontekstu Turske. Uopće ih nije bilo ili su postojala malobrojna istraživanja odnosa između akademskih voljnih strategija i akademskog postignuća u obrnutom okruženju za učenje. Ovom studijom nastojala se ispuniti ta praznina.

\section{Svrha istraživanja}

Cilj istraživanja bio je istražiti postojanje korelacije između akademskih voljnih strategija i akademskog postignuća studenata upisanih u program obrazovanja budućih učitelja, a koji su iskusili obrnuto okruženje za učenje. Istraživačko pitanje koje je vodilo studiju bilo je: "Postoji li statistički značajna veza između akademskih voljnih strategija i akademskog postignuća studenata u obrnutoj učionici?" Iz te perspektive istraživao se odnos između dviju varijabli - akademskih voljnih strategija i studentskog postignuća u obrnutom okruženju za učenje - kako bi se utvrdili smjer, oblik i stupanj povezanosti.

\section{Povezana literatura}

\section{Akademske voljne strategije}

Volja je stara varijabla definirana kao radnja koja se poduzima da bi se ostvario cilj. Povijesno gledano, izvire iz proučavanja ljudske motivacije i djelovanja Williama Jamesa iz 1902. godine (Ach, 1910) i nastojanja da se izbjegnu teorijske kompleksnosti; stoga se volja smatrala kategorijom motivacije. Kuhl $(1984,1987)$ i Gollwitzer $(1996$, 1999) ponovno su je uveli u modernom pristupu kao teoriju kontrole djelovanja. Drugim riječima, volja je svjesna radnja (Clara, 2016; Vygotsky, 1987, str. 220) koja izvire iznutra gdje se kodira, pohranjuje i predstavlja neovisno o vanjskom učinku. Vrsta je to svjesno stvorenog odraza kognitivnih stanja (Jeannerod, 2009). Drugim riječima, volja ima dodatnu moć objašnjenja razloga zbog kojeg individue ili nastavljaju redovno djelovanje ili od istog odustaju (Elsborg, Wikman, Nielsen, Tolver i Elbe, 2016). Stoga ona određuje prijelaz od namjere do radnje (Broonen, 2010; Forstmeier i Rüddel, 2008; Hikkerova, Ilouga i Sahut, 2016). 
Voljna strategija izravno vodi učeničkim emocijama. Rezultati nekoliko istraživanja (Burić i Sorić, 2012; Pekrun i sur., 2004; Valle i sur., 2003) otkrivaju da učenici mogu regulirati emocije i motivaciju kada se učinkovito koriste voljnom strategijom. Uvjeti održavanja sklonosti za postizanjem cilja označavaju voljni aspekt tog procesa. Voljni aspekti predstavljaju omogućavanje cilja učenja štiteći volju pojedinca za učenjem od nemotiviranosti za postizanjem cilja (Cooper i Corpus, 2009; McCann i Garcia, 1999). Samoregulacijske vještine kontrole prirodno su konstruirane kao voljne i vjeruje se da imaju indikativnu ulogu u učeničkom postignuću na zadatcima školovanja (McCann i Turner, 2004; Mokri, 2012; Turner, Husman i Schallert, 2002; Turner i McCann, 2000).

Prema Corno i Kanfer (1993, str. 311) pet je kategorija voljne kontrole u obrazovnom kontekstu. One su: metakognicija, motivacija, emocija i dvije okolinske strategije kontrole, tj. kontrola situacije zadatka i kontrola drugih u okruženju zadatka (str. 312). Od tih se pet kategorija najviše pažnje pruža metakogniciji, motivaciji i kontroli okoline pa se smatraju strategijama nadgledanja osjećaja i entuzijazma u akademskim kontekstima (Corno i Kanfer, 1993; Deimann i Bastiaens, 2010; Pekrun, 2000). Potonje su manje istražene (McCann i Garcia, 1999) i njihovi jedinstveni učinci na namjeru učenja vrijedni su istraživanja ciljanih ishoda (Corno, 1993, 2001; Wolters i Rosenthal, 2000). Kako bi zadržali motivaciju, zaštitili i povećali angažman pri susretu s teškoćom ili nemotiviranosti za zadatak, učenici se koriste raznim voljnim strategijama, kao i kognitivnim i metakognitivnim strategijama tijekom rješavanja zamornih školskih zadataka. Neki poticaji u regulaciji motivacije i emocija uključuju preporuke Kuhla (1985) koji navodi "podsjećanje na vlastite ciljeve, nagrađivanje za završetak propisane količine učenja” (McCann i Garcia, 1999, str. 262) i razmišljanje o posljedicama grešaka i krivih putova kao na uobičajene odgovore učenika koji reagiraju prema voljnim strategijama. Primjenjujući voljne strategije, učenici imaju veću sposobnost za jačanje vlastite motivacije i rada na postizanju akademskih zadataka; zadatke mogu rješavati brže i uspješnije (Husman, McCann i Crowson, 2000; Molokoli, 2014). Wolters i Rosenthal (2000) ističu kako učenička upotreba voljnih strategija služi kao mehanizam putem kojeg stavovi, zajedno s kognicijom, objašnjavaju veći angažman i ustrajnost na akademskim zadatcima.

\section{Obrnuta okolina učenja}

S inovacijama u tehnologiji podučavanja i napretkom u aktivnoj pedagogiji učenja neki su edukatori potaknuli upotrebu intuitivnog obrazovnog modela nazvanog obrnuto učenje ("Obrnuto učenje 3.0"; Globalna inicijativa obrnutog učenja, 2017; Şahin i Fell-Kurban, 2016). Obrnuto učenje platforma je na kojoj učenik doseže vlastiti put učenja, primjeren njegovim/njezinim individualnim potrebama (Bergmann i Sams, 2012). Obrnuto učenje uključuje asinkrona online predavanja zahvaljujući kojima učenik uči izvan razreda. Nakon toga, kada se susretne s učiteljem, interakciju s njim i vršnjacima ostvaruje u aktivnostima učenja u razredu (Bergmann i Sams, 2013; Bishop i Verleger, 2013). Vrijeme u razredu rezervirano je za otkrivanje, nadogradnju 
i razmjenu zamisli. Cilj je promocija učeničkih složenih vještina rasuđivanja pri angažmanu na intelektualnim i poticajnim nastavnim iskustvima. Prilikom primjene pristupa obrnutog učenja, učenici se koriste vlastitim vještinama zapamćivanja i razumijevanja, kao kognitivnim zadatcima niže razine, prije nego dođu u razred ili, drugim riječima, svojim individualnim prostorom. Onda se okreću kognitivnim vještinama višeg reda, poput analize i stvaranja, među drugima u učionici ili, drugim riječima, u grupnom prostoru (Karbach, 2014; Lee, Lim, i Kim, 2017).

U obrnutom učenju, koje je postalo globalni pokret (Akademija obrnutog učenja, 2018; PRNewswire, 2018), učitelji pripremaju predmetne videofilmove pred razredom, tako da se znanje prenosi na učenike koji gledaju video. Dodatno, ostali predmetni materijali, odnosno dnevnički zadatci, forumi za raspravu itd., dostupni su putem digitalne online platforme. Učenici koji gledaju obrnuti video, dolaze na razredne susrete s pitanjima koja će aktivirati njihovo mišljenje višeg reda. Stoga se, umjesto izravne poduke, koristi prostor za učenje dinamične učionice i interaktivne skupine (Knewton, 2015; Mok, 2014). U tom pogledu učitelj ima ulogu moderatora koji svakom učeniku omogućuje primjenu koncepata, angažman na predmetnom sadržaju, internaliziranje i razvoj znanja $u$ razredu. Učenici mogu konstruirati novo znanje surađujući i raspravljajući s vršnjacima (Bergmann i Sams, 2012; Demiralay, 2014; Gencer, 2015).

$\mathrm{U}$ isto vrijeme pristup obrnutog učenja daje priliku predavačima u prostoru institucija višeg obrazovanja da uvaže sve stilove učenja studenata. Okretanjem učionice predavači postaju kvalificirani za osmišljavanje i razvijanje iskustava aktivnog učenja, uzimajući u obzir potrebe svakog studenta (Berrett, 2012; McLaughlin i sur., 2014). Najvažnije, obrnuto učenje usredotočeno je na učenika/studenta, a svaki učenik ima priliku ostvariti samodisciplinu jer je obavezan doći na nastavu s osnovnim razumijevanjem ciljeva učenja i predmetnog materijala koje dobiva od učitelja. Kada imaju osnovnu percepciju ciljeva učenja, učenici mogu biti u potpunosti aktivni i angažirati se u razrednoj raspravi koristeći se percepcijama višega reda. Uz pomoć okretanja učenici mogu usvojiti sadržaj samoregulirajućim tempom i odrediti vrijeme i količinu sadržaja koji gledaju na digitalnoj online platformi. Nakon te faze učitelji puštaju učenike da stječu interaktivna iskustva učenja i aktivno sudjeluju u ekosustavu učenja. Potom se ti učenici mogu potaknuti na kritičko i kreativno mišljenje. Također, učitelji daju povratne informacije. Učenički se uspjeh može njegovati putem kritičkog kognitivnog i metakognitivnog razvoja te promocije napretka suradnje, uz pomoć osiguravanja bogatih otvorenih iskustava (Berrett, 2012; Bergmann i Sams, 2012; McLaughlin i sur., 2014). Mnoge su istraživačke studije koje mjere učeničku izvedbu i percepciju (Lane-Kelso, 2015; Wasserman, Quint, Norris i Carr, 2017) ponekad u vezi s kontekstom samoučinkovitosti i samoregulacije (Lai i Hwang, 2016).

Kao pedagogija pristup se obrnutog učenja u nastavi koristi od 2012. godine, kada je osmišljen, i od tada traga za učinkovitosti s pomoću kvalitativnih i kvantitativnih paradigmi (Birgili i Fell-Kurban, 2017; Birgili, İler i Engin-Demir, 2016; Long, 
Cummins i Waugh, 2017; McKeown, 2016; Moffett, 2015; Moran i Milsom, 2015; Redekopp i Ragusa, 2013). Pristup okretanja ispitivao se istraživanjem i sveobuhvatnim tezama (Files, 2016; Guggisberg, 2015; Saunders, 2014; Sirakaya, 2015; Sun, 2015; Turan, 2015; Zuniga, 2015). Ipak, razumijevanje odnosa između učeničke upotrebe voljnih strategija i njihova akademskog postignuća u okolini obrnutog učenja bio je na početcima. Stoga su ti konstrukti istraženi u okviru ove studije.

\section{Metode}

\section{Dizajn istraživanja}

Ova istraživačka studija zasnovana je na korelacijskom ili asocijativnom istraživačkom dizajnu. U ovom dizajnu istraživanja ispitivao se odnos između dviju ili više varijabli, bez razmatranja utjecaja neovisne na ovisnu varijablu (Fraenkel, Wallen, i Hyun, 2009). Podatci su prikupljeni kako bi se utvrdilo postoji li, i u kojoj mjeri, odnos između dviju ili više kvantitativnih varijabli (Gay, Mills, i Airasian, 2011). Provedeno je korelacijsko istraživanje (prema Fraenkel, Wallen i Hyun, 2009) kako bi se razjasnili pojmovi utvrđivanjem odnosa među varijablama. S obzirom na to da je studija istraživačka, utvrđivanje postojanja korelacije između postignuća studenata iz kolegija i upotreba akademskih voljnih strategija može proširiti razumijevanje tih pojava.

\section{Skupina ispitanika}

Trideset dva studenta dodiplomskog programa za obrazovanje učitelja na sveučilištu u Turskoj, s iskustvom u okolini obrnutog učenja, sudjelovala su u ovoj studiji. Od njih 32, dvoje nije bilo uključeno u studiju jer njihovi rezultati na instrumentu mjerenja nisu bili valjani. Prema deskriptivnoj statistici sudionika, 30 studenata (3 muškarca i 27 žena) bili su u dobnom rasponu od 19 do 43 godine starosti i svi su bili studenti prve godine u relevantnom akademskom semestru. Tijekom jednog od uvodnih kolegija, $\mathrm{u}$ sklopu programa za obrazovanje učitelja, učili su predmetni sadržaj i osnovne metode i tehnike podučavanja u tom polju.

\section{Instrument prikupljanja podataka}

Razina upotrebe akademskih voljnih strategija studenata mjerena je Upitnikom akademskih voljnih strategija (AVSI) na petostupanjskoj Likertovoj skali (McCann i Turner, 2004). Skala je sastavljena od dva dijela; prvi je uključivao demografske podatke, a drugi 20 stavki u vezi s akademskim voljnim strategijama. Prije sakupljanja podataka, instrument je testiran u smislu razumljivosti, dužine i tehničke prirode stavki. Provedeni su kognitivni intervjui sa studentima dobrovoljcima, koji su s dva različita fakultetska odsjeka. Kognitivni intervjui (Willis, 1999) primijenjeni su kako bi se utvrdile informacije koje nisu dobivene upotrebom AVSI. Tijekom pregledavanja upitnika, verbalizirane su misli i osjećaji sudionika. Taj proces imao je dva oblika, "razmišljanje naglas" (Ericsson i Simon, 1990) i “verbalno ispitivanje”. Četiri sudionika dobrovoljca tumačila su stavke AVSI-a verbalnim istraživačkim pitanjima. 
Nakon što su dobrovoljci naglas pročitali stavke, od njih se tražilo da pitaju ima li teško razumljivih dijelova. Nakon toga se procjenjivala dužina i tehnička struktura stavki i o tome se raspravljalo zajedno $s$ dobrovoljcima.

Instrument je sastavljen od tri poddimenzije: poboljšanje samoučinkovitosti (činilo ga je devet stavki), negativno zasnovani poticaji (činilo ih je šest stavki) i radnje za smanjenje stresa (činilo ih je pet stavki). Koeficijent pouzdanosti, zasnovan na svojoj originalnoj inačici koju je sačinjavala skala od 30 stupnjeva (McCann i Garcia, 1999), bio je $\alpha=, 87$.Za tri čimbenika podskale iznosio je $\alpha=, 82$ za povećanje samoučinkovitosti, $\alpha=, 73$ za negativno zasnovane poticaje i $\alpha=, 69$ za radnje smanjenja stresa. $S$ druge strane, izmjereni Cronbach alfa koeficijent pouzdanosti iznosio je ,71 u ukupnom AVSI rezultatu, što je ukazivalo na umjerenu razinu unutarnje konzistentnosti skale s tim specifičnim uzorkom (Cohen, 1988). Dodatno, rezultati predtestova i posttestova podržavali su stabilnost skale $(\mathrm{r}=, 72 ; \mathrm{p}<, 001)$. Reakcija "Podsjećam se na to da obično dobro prolazim na ispitima $\mathrm{i} / \mathrm{ili}$ drugim zadatcima kada se držim rasporeda učenja" (stavka 2) prikazana je supskalom povećanja učinkovitosti, a "Mislim o mogućim negativnim posljedicama slabog uspjeha u ovom razredu" (stavka 17) primjer je podskale zasnovane na negativnim poticajima. $S$ druge strane, "Ako imam teškoća, nazovem prijatelja iz razreda i s njim/njom raspravim zadatak/materijal" (stavka 4) primjer je podskale radnji za smanjivanje stresa.

Konvergentna i divergentna valjanost AVSI-a provjerene su Rosenbergovom Skalom samopoštovanja (1965) i Skalom odgode zadovoljstva (Ray i Najman, 1985). Dodatno, drugi instrumenti, odnosno Skala regulacije negativnih raspoloženja (Catanzaro i Mearns, 1990) i Skala akcijske kontrole (Kuhl, 1994) također su uspoređene s AVSI s obzirom na njihovu indikativnost za studentske sklonosti samoreguliranom ponašanju i druge povezane konstrukte (npr. pažnju, inicijativu, impuls, disciplinu). Statistički rezultati nisu bili značajni. Moglo se zaključiti da odabrane skale mjere globalni fokus na karakteristike pojedinca, a AVSI mjeri vrlo tijeni fokus na akademske situacije, ovisno o specifičnoj vrsti kolegija. Dodatno, još jedna slavna skala, upitnik Motivacijske strategije učenja (MSLQ) (Pintrich, Smith, Garcia, i McKeachie, 1991), bila je u korelaciji s AVSI. U ovoj je studiji pronađena skromna pozitivna povezanost između motivacije studenata i njihova angažmana pri učenju s voljom. Taj rezultat pokazao je da volja treba biti promatrana kao odvojeni konstrukt. Ipak, zbog valjanosti se činilo da postoji minimalno preklapanje jer su oba instrumenta ovisila o sklonosti prema samoreguliranom ponašanju. Podskala učenja MSLQ-a također je pokazala različitost prema AVSI, što znači da su stavke na AVSI formirane neovisnim čimbenicima i mjerile zasebne i jedinstvene voljne strategije samoregulacije.

\section{Proces skupljanja podataka}

Nakon dobivene etičke dozvole za studiju, započelo je skupljanje podataka. Skupljena su studentska postignuća iz akademskih kolegija (njihove ocjene iz kolegija) putem njihovih samoizvještaja, nakon što su pregledali svoje transkripte na kraju semestra. Sudionici studije u programu obrazovanja budućih učitelja bili su na prvoj godini 
studija i iskusni u obrnutom učenju. Trebali su proučavati sadržaj tjedna i gledati videomaterijale obrnutog učenja koje im je zadao predavač. Tijekom kolegija također su trebali čitati članke ili poglavlja knjiga, kako bi vodili dnevničke zapise i bilježili razmišljanja o zadanom štivu vezanom uz osnovne metode i tehnike podučavanja. Svi zadatci ocjenjivani su online sustavom.

Tijekom primjene AVSI cjelovite stavke projicirao je i čitao primarni istraživač. Nakon procesa sakupljanja podataka, iz skale su isključeni četvrta i sedamnaesta stavka. Studija je provedena i preliminarna analiza nastavljena s AVSI-om koji je uključivao 18 stavki.

\section{Analiza podataka}

Ova studija nastojala je odgovoriti na istraživačko pitanje: “Koji je odnos između akademskih voljnih strategija i postignuća studenata na učiteljskom fakultetu u okolini obrnutog učenja?" Drugim riječima, pitanje "Koliko je snažna veza između akademskih voljnih strategija i postignuća studenata u okolini obrnutog učenja?” istraženo je jednostavnom analizom linearne korelacije (Tabachnick i Fidell, 2013) između dviju varijabli. Prva, prediktorska varijabla, u ovoj je studiji akademsko postignuće studenata. Druga, kriterijska varijabla, rezultati su akademskih voljnih strategija. Obje su varijable kontinuirane i imaju intervalnu skalu mjerenja (vidi Tablicu 1). a razina postavljena je na .05 za statističku značajnost. Prije analize korelacije provjerene su pretpostavke normalnosti kako bi se utvrdila valjanost analize. Zbog ustanovljene normalnosti (Field, 2009) kao metoda analize parametrijske statistike koristila se Pearsonova korelacija.

Tablica 1

\section{Rezultati}

$\mathrm{U}$ ovom dijelu predstavljamo rezultate deskriptivne i inferencijalne statistike o tome postoji li značajna korelacija između primjene akademskih voljnih strategija studenata i akademskih postignuća u okolini obrnutog učenja. U preliminarnom ispitivanju normalnosti potvrđene su pretpostavke nasumičnog uzorkovanja i neovisnog promatranja. Asimetrija, vrijednosti spljoštenosti i histogrami provjereni su na ukupnom AVSI rezultatu, njegovim poddimenzijama i uspjehu iz kolegija, zbog razumijevanja varijanci i normalnosti. Vrijednosti asimetrije i spljoštenosti za svaku varijablu bile su između +3 i -3 , što je zadovoljilo manju varijaciju i manje ekstremne slučajeve u podatcima (Field, 2009). Ipak, čini se kako su histogrami vizualno predstavljali asimetriju. Posebno su rezultati akademskih voljnih strategija i njihove poddimenzije - povećanje samoučinkovitosti, negativno zasnovani poticaji i radnje smanjivanja stresa, tim redom - ukazivali na nepostojanje ekstremnih slučajeva i normalnost. Dodatno, rezultati Kolmogorov-Smirnov i Shapiro-Wilk testova nisu bili značajni za ukupne rezultate AVSI ( $\mathrm{p}>, 05)$. Slično tomu rezultat nije bio značajan ni za rezultate postignuća ( $\mathrm{p}>, 05)$. Na osnovi podataka može se zaključiti da je zadovoljena pretpostavka normalnosti. 
Dodatno, deskriptivna analiza rezultata studentskog akademskog postignuća i akademskih voljnih strategija sažeta je u Tablici 2.

Tablice 2 i 3

Nadalje, rezultati (Tablica 3) pokazuju statistički značajnu povezanost između AVSI rezultata i akademskog postignuća studenata u obrnutom okruženju učenja $(r=, 39$, $\mathrm{p}=, 04<, 05$ ), prema Pearsonovu produkt-moment koeficijentu korelacije (Cohen, 1988). To znači da je postojala umjerena korelacija između rezultata postignuća i rezultata akademskih voljnih strategija. Slično tomu rezultati dalje analize također su pokazali značajnu povezanost između akademskog postignuća i AVSI poddimenzija povećanja samoučinkovitosti $(\mathrm{r}=, 58, \mathrm{p}<, 01)$ i radnji za smanjenje stresa $(\mathrm{r}=, 46, \mathrm{p}<, 01)$, ali ta povezanost nije bila značajna za negativno zasnovane poticaje $(\mathrm{r}=-, 13, \mathrm{p}>, 01)$.

\section{Rasprava}

Ova je studija istražila odnos između akademskih voljnih strategija i učeničkih postignuća u obrnutoj okolini učenja jednostavnom analizom korelacije. Rezultati su otkrili da je, s porastom učeničke sposobnosti primjene akademskih voljnih strategija, rasla i vjerojatnost višeg akademskog postignuća, tj. ocjena iz kolegija. Taj rezultat podržava neke akademske pretpostavke iz povezane literature i sličan je prijašnjim istraživanjima (Burić i Sorić, 2012; Hinnant-Crawford i sur., 2016; McCann i Turner, 2004; Molokoli, 2014; Shepherd, 2006).

Burić i Sorić (2012) ispitali su odnos između emocija i akademskog postignuća srednjoškolaca na 365 testova, unutar okvira teorije kontrole vrijednosti. Otkrili su da su učenici, kada su učinkovito primjenjivali voljne strategije, regulirali vlastite emocije i motivaciju. Stoga postoji indirektan učinak regulacije emocija na kognitivni angažman u akademskim studijama, što može voditi pozitivnom učinku na akademsko postignuće (McCann i Turner, 2004). Trenutna studija također je ispitala važnost akademskih voljnih strategija i količinu i mjeru u kojoj ih učenici primjenjuju. Istaknula je da dvije poddimenzije AVSI-a, povećanje samoučinkovitosti i strategije smanjivanja stresa mogu biti od koristi i učinkovite za učeničko postignuće tijekom godina njihova visokog obrazovanja. Ipak, treba istaknuti da poddimenzija "negativni poticaji" može biti štetna u procesu učenja. Rezultati se mogu kombinirati s nekim postojećim nalazima u vezi s voljnom kontrolom kako bi se dobili novi uvidi za daljnje istraživanje. Neki od postojećih rezultata potvrdili su da obrazovanje voljne kontrole može imati pozitivan učinak na raznolike motivacijske utjecaje. Tako, za mnoge učenike, ti utjecaji imaju pozitivan odnos s njihovim kognitivnim zalaganjem, što može utjecati na akademsko postignuće (Garcia i sur., 1998; Husman, McCann i Crowson, 2000; McCann i Garcia, 1999).

S druge strane, u literaturi se raspravlja o strategiji akademske voljnosti u smislu njezine medijatorske uloge (Corno i Kanfer, 1993; Dewitte i Lens, 2000; Garcia, McCann, Turner i Roska, 1998; Husman i sur., 2000; Kuhl, 1985). McCann i Turner (2004) su, npr. otkrili da akademske voljne strategije nisu imale izravan učinak na 
učeničku predmetnu izvedbu, što je izmjereno njihovom predmetnom ocjenom na kraju semestra/razreda. Dodatno, rezultati analize njihova puta pokazali su kako akademske voljne strategije mogu imati izravan učinak na učeničku upotrebu strategija učenja izmjerenu elaboracijom, kritičkim mišljenjem ili vježbom među drugima. Ti rezultati također pokazuju indirektan učinak koji može osnažiti utjecaj nekih motivacijskih čimbenika na upotrebu strategija učenja. Ova studija može imati prominentnu ulogu za raspravu o odnosu između akademskih voljnih strategija i predmetne izvedbe. Dodatno, rezultat prijašnjeg istraživanja istaknuo je značajan indirektan učinak regulacije na postignuće učenika (Hinnant-Crawford i sur., 2016). U istraživanju Husman, McCann i Crowson (2000) naglašena je posrednička uloga volje ili voljne kontrole u učeničkoj kogniciji u akademskim situacijama vezanim uz zadatak. Naime, voljna kontrola predstavlja sposobnost primjene strategija za zagovaranje i zaštitu motivacije prilikom zalaganja na raznolikim predmetnim zadatcima, a u cilju ostvarenja akademskih ciljeva. Dodatno, studija je istraživala strategije kontrole radnji kao posrednika između zalaganja u učenju i prilike za uspjeh ili za postignuće vezanih ponašanja. Ovaj komentar odnosi se na činjenicu da voljne strategije treba istraživati kao posrednika (Dewitte i Lens, 2000). Dafna i Haieman's (2005) otkrili su da stariji učenici uče kopirajući tehnike mnogo boljih u školskim zadatcima. Ti nalazi također su podržani pretpostavkom Corno (2004) kako studenti na višoj školi imaju sklonost češćoj primjeni akademskih voljnih strategija.

Rezultat studije također je kompatibilan s istraživanjem Molokoli (2014) na skupini od 150 učenika devetog razreda iz dviju državnih srednjih škola smještenih u četvrti Rustenburg u Sjeverozapadnoj pokrajini Južnoafričke Republike. Svrha ove studije bila je razviti, implementirati i evaluirati model kako bi se povećala učenička primjena voljnih strategija i zatim poboljšalo postignuće učenja i poučavanja. Rezultati predtesta, posttesta i testa retencije pokazali su da šest voljnih strategija, na primjer planiranje, voljna samoučinkovitost, pritisak samokontrole, nadgledanje namjere itd., doprinose visokoj izvedbi. Učenici s visokom izvedbom bolji su u kontroli emocija i bolje reagiraju u slučaju neuspjeha. To je u skladu s rezultatima trenutne studije koji ukazuju na činjenicu da su postignuti predmetni rezultati bolji što učenici imaju više koristi od radnji smanjivanja stresa i povećanja samoučinkovitosti.

\section{Zaključci}

Ova studija istraživala je odnos između voljnih akademskih strategija i akademskih postignuća studenata u obrnutoj okolini učenja na sveučilištu u Turskoj. Istraživanje je otkrilo značajan umjereni odnos između postignuća studenata i AVSI rezultata. Može se zaključiti da studenti koji su izloženi pristupu obrnutog učenja mogu regulirati svoje emocije i motivaciju prema zadatcima kolegija kako bi povećali ishode učenja. Od početaka do kraja semestra učili su sadržaje nacionalnog kurikula i osnovne metode poučavanja i tehnike u polju. Nalazili su svakodnevne primjere povezane sa sadržajem iz nacionalnih i internacionalnih izvora, pisali dnevnike i osvrte u vezi s tjednim iskustvom i sadržajima. S tim iskustvima studenti su razvili prilagodbu i povećali vjeru 
u vlastitu učinkovitost. Mogli su biti bolji u samouvjeravanju u važnost zadatka, ispita i pisanog rada, i tada se na spomenute stvari usredotočiti. Motiviraju se govoreći "ti to možeš” te zadržavajući angažman držeći se rasporeda učenja, podsjećajući se da obično dobro prolaze na zadatcima ili ispitima. Štoviše, studenti koji su imali iskustvo obrnutog učenja bili su sposobniji u pronalaženju kreativnih načina da svoja radna nastojanja učine privlačnijima tijekom vremena studiranja (McCann i Garcia, 1999). Kada se suoče s teškoćama, preferiraju raspraviti zadatak ili materijal s prijateljem, aktivnost koja je dopuštena. Neki su sposobni koristiti se metodama opuštanja kako bi se više usredotočili na studij. Te strategije pokazale su da što su više studenti primjenjivali voljne strategije u svojim predmetima, to je njihovo akademsko postignuće tijekom kolegija bilo bolje.

Treba uzeti u obzir kako voljne strategije variraju od studenta do studenta i da se primjena mnogostrukih pristupa može naučiti. Ipak, voljne se strategije ne mogu naučiti kratkotrajnom podukom (Corno, 2004). Studenti trebaju internalizirati akademska pravila, preuzeti odgovornost i učiti kako se nositi sa sve većom složenošću akademskog postignuća. Od najveće je važnosti način na koji predavač motivira studente pridobivajući njihovu pažnju, prezentirajući sadržaj ili im pomažući da ih predstave. Spomenuto gradi učeničku razinu samopouzdanja i njihovo postignuće, što posljedično doprinosi povećanju zadovoljstva.

\section{Ograničenja, implikacije i prijedlozi za daljnja istraživanja}

Ova se studija može provesti na različitim uzorcima studenata s raznih studijskih grupa na Fakultetu za obrazovanje i u mnogim okruženjima. U obliku longitudinalne studije istu se skupinu studenata može pratiti u smislu napretka $u$ korištenju akademskih voljnih strategija. Štoviše, ova studija predstavlja kvalitativno istraživanje koje se može ispitati putem dizajna miješanih metoda (Tashakkori i Teddlie, 1998). Učinak akademskih voljnih strategija na postignuće također se može istražiti putem eksperimentalno-kontrolnih uvjeta. Za daljnje istraživanje ta studija može se redizajnirati upotrebom proširenih podataka s više sudionika. Neke varijable, poput različitih osobina studenata ili raznolikih okruženja učenja, mogu se odabrati za provjeru njihova učinka na vezu između akademskih voljnih strategija i akademskog postignuća. Među preporukama za institucije visokog obrazovanja, kao učitelji/predavači trebamo podržati sposobnost naših učenika/studenata da razviju akademske navike učenja koje mogu pridonijeti njihovu postignuću. Stoga bi studenti postali sposobni regulirati svoje aktivnosti učenja i razviti pozitivne radne navike pri bavljenju složenim akademskim zadatcima.

Kao praktičari znamo da obrnuta okolina učenja može promicati učeničko razmišljanje i interakciju u skupini vršnjaka. Preporučujemo predavačima primjenu tehnika za unapređivanje strategija voljne kontrole kako bi povećali učinkovitost radnih navika svojih studenata/učenika, bez odgađanja obaveza. Trebali bi učenike podučiti načinima pozitivnog mišljenja po završetku zadatka i aprecijaciji vrijednosti zadataka. 